\title{
EDITORIAL
}

\section{Pulmonary gas exchange on Mount Everest}

\author{
J.B. West
}

The paper by PeAcock and Jones [1], "Gas Exchange at Extreme Altitude: Results from the British 40th Anniversary Expedition", presented in this issue of the Journal, reports fascinating new data recorded at extreme altitudes (up to 8,000 m) on Mount Everest. Among the interesting findings, was the fact that, on the South Col (altitude $8000 \mathrm{~m})$, alveolar oxygen tension $\left(\mathrm{PA}, \mathrm{O}_{2}\right)$ (measured with a fuel cell) was about $5.1 \mathrm{kPa}$ (38 torr) and arterial oxygen saturation $\left(\mathrm{Sa}, \mathrm{O}_{2}\right)$ (measured with a pulse oximeter) was about $70 \%$, emphasizing the extraordinary degree of hypoxaemia experienced by climbers at extreme altitudes. The results of the British 40th Anniversary Expedition agree remarkably well with those of the 1981 American Medical Research Expedition to Everest [2, 3].

The most important factor in the process of acclimatization, which helps to maintain the arterial oxygen tension $\left(\mathrm{Pa}, \mathrm{O}_{2}\right)$ and $\mathrm{Sa}, \mathrm{O}_{2}$ at viable levels, is extreme hyperventilation. This defends the alveolar $P A, \mathrm{O}_{2}$ in the face of the fall in partial pressure of oxygen $\left(\mathrm{PO}_{2}\right)$ in the surrounding air. In addition, the reduction in partial pressure of carbon dioxide $\left(\mathrm{PCO}_{2}\right)$ causes a respiratory alkalosis, which also assists in maintaining $\mathrm{Sa}, \mathrm{O}_{2}$ by increasing the oxygen affinity of the haemoglobin. It is interesting that, as shown in the paper by PEACOCK and JONES [1], the values for $P \mathrm{~A}, \mathrm{O}_{2}$ measured on Operation Everest II were much lower [4], apparently because these subjects were less well acclimatized [5].

One of the most stimulating topics in the area of highaltitude medicine and physiology this century has been the challenge of climbing Mount Everest, especially without supplementary oxygen. In the closing stages of the last century, climbers were very pessimistic about reaching such great altitudes. For example, in 1876, T.W. Hinchliff, President of the (British) Alpine Club, wrote gloomily after visiting Santiago, Chile [6]: "I could not repress a strange feeling as I looked at Tupungato (21,550 feet) and Aconcagua (23,080 feet) and reflected that endless successions of men must in all probability be forever debarred from their lofty crests.... Those who, like Major Godwin-Austen, have had all the advantages of experience and acclimatization to aid them in attacks upon the higher Himalayas agree that 21,500 feet $(7,050 \mathrm{~m})$ is near the limit at which man ceases to be capable of the slightest further exertion".

However, in 1909, an Italian aristocrat, the Duke of the Abruzzi, led an expedition to the Karakorum, which, as the Duke's biographer and physician, DE FILIPPI [7] wrote, was designed "to contribute to the solution of

Correspondence: J.B. West, University of California, San Diego, Dept of Medicine 0623, 9500 Gilman Drive, La Jolla, CA 92093-0623, USA. the problem as to the greatest height to which man may attain in mountain climbing". The expedition reached $7,500 \mathrm{~m}$ and the feat prompted Douglas et al. [8] to argue that the lung must have secreted oxygen. Indeed, during the Pikes Peak expedition of 1911, Douglas et al. [8] believed that they had found strong evidence of oxygen secretion in acclimatized subjects.

In 1919, Alexander M. Kellas, a Scottish chemist and physiologist, made an extensive theoretical study of the physiological problems associated with climbing Everest [9], but the work was never published in an accessible form, and most high-altitude physiologists are unaware of it. Kellas concluded that the mountain could be climbed without supplementary oxygen if the technical difficulties were not too great, but he died dramatically when the initial Everest reconnaissance had its first view of Everest in 1921.

In 1924, E.F. Norton climbed to within $300 \mathrm{~m}$ of the Everest summit without supplementary oxygen, but it was 54 yrs before the last $300 \mathrm{~m}$ were eventually conquered! In 1930, the Italian physiologist MARGARIA [10] measured maximal oxygen consumptions at very low barometric pressures in a low-pressure chamber, and concluded that man could not reach the Everest summit without supplementary oxygen. A few years later, HENDERSON [11] came to the same conclusion based on measurements of maximal oxygen consumption made in the field. But by 1958, 5 yrs after Hillary and Tenzing had made the first ascent (with supplementary oxygen), the British physiologist PugH [12] was less willing to make a categorical statement, and wrote that it was "unlikely that the mountain could be climbed without oxygen equipment without serious risk".

It was not until 1978 that Reinhold Messner and Peter Habeler astounded both physiologists and mountaineers with their "oxygenless" ascent of Everest. MESSNER [13] reported his sensations on reaching the summit in lyrical terms: "Now, when... I have nothing more to do than breathe, a great peace floods my whole being. I breathe like someone who has run the race of his life and knows that he may now rest for ever... In my state of spiritual abstraction, I no longer belong to myself and to my eyesight. I am nothing more than a single, narrow, gasping lung, floating over the mists and the summits".

Some physiologists were reluctant to believe the feat at first (emergency oxygen had been taken), but other "oxygenless" ascents soon followed, including the spectacular solo ascent by Messner in 1981.

This first ascent without supplementary oxygen prompted a theoretical analysis of the most critical factors on the Everest summit [14]. These were: 1) the barometric pressure; 2) the extent of the hyperventilation; and 3) 
the maximal oxygen uptake. The first measurements of the barometric pressure and $P \mathrm{~A}, \mathrm{CO}_{2}$ on the summit were obtained by the 1981 American Medical Research Expedition to Everest. Barometric pressure was a little higher than expected at $33.7 \mathrm{kPa}$ (253 torr), probably because the weather was so fine [15]. The $P \mathrm{~A}, \mathrm{CO}_{2}$ was astonishingly low at $0.9-1.1 \mathrm{kPa}$ (7-8 torr) [3]. Maximal oxygen uptake was not measured on the actual summit but in the Laboratory Camp at $6,300 \mathrm{~m}$, when the well-acclimatized climbers breathed $14 \%$ oxygen, which gave the same $P_{\mathrm{O}_{2}}$ as the Everest summit [16]. The value of just over $1 \mathrm{~L} \cdot \mathrm{min}^{-1}$ agreed well with the ascent rate of Messner and Habeler near the summit. Four years later in 1985, a simulated climb of Everest in a low-pressure chamber, Operation Everest II, greatly clarified the physiological adaptations, including studies of the pulmonary circulation, pulmonary gas exchange and muscle biopsies [17].

The fact that the Everest summit is so near the limit of human tolerance to severe hypoxia is a remarkable cosmic coincidence, which has stimulated great interest in the physiology of extreme hypoxia. The first "oxygenless" ascent and the subsequent understanding of the physiological mechanisms involved constitute one of the scientific sagas of the century.

\section{References}

1. Peacock AJ, Jones PL. Gas exchange at extreme altitude: results from the British 40th Anniversary Everest Expedition. Eur Respir J 1997; 10: 1439-1444.

2. Winslow RM, Samaja M, West JB. Red cell function at extreme altitude on Mount Everest. J Appl Physiol: Respirat Environ Exercise Physiol 1984; 56: 109-116.

3. West JB, Hackett PH, Maret KH, et al. Pulmonary gas exchange on the summit of Mt. Everest. J Appl Physiol:
Respirat Environ Exercise Physiol 1983; 55: 678687.

4. Sutton JR, Reeves JT, Wagner PD, et al. Operation Everest II: oxygen transport during exercise at extreme simulated altitude. J Appl Physiol 1988; 64: 1309-1321.

5. West JB. Rate of ventilatory acclimatization to extreme altitude. Respir Physiol 1988; 74: 323-333.

6. Hinchliff TW. Over the Sea and Far Away. London, Longmans Green, 1876; pp. 90-91.

7. de Filippi F. Karakorum and Western Himalaya. London, Constable, 1912; p. xv.

8. Douglas CG, Haldane JS, Henderson Y, Schneider EC. Physiological observations made on Pike's Peak, Colorado, with special reference to adaptation to low barometric pressures. Philos Trans $R$ Soc Lond Biol Sci 1913; 203: 185-381.

9. West JB, Alexander M. Kellas and the physiological challenge of Mt Everest. J Appl Physiol 1987; 63: 3-11.

10. Margaria R. Die Arbeitsfähigkeit des Menschen bei vermindertem Luftdruck. Arbeitsphysiologie 1930; 141: 233-261.

11. Henderson Y. The last thousand feet on Everest. Nature 1939; 143: 921-923.

12. Pugh LGCE. Muscular exercise on Mt Everest. $J$ Physiol (Lond) 1958; 141: 233-261.

13. Messner R. Everest: Expedition to the Ultimate. London, Kaye \& Ward, 1979.

14. West JB, Wagner P. Predicted gas exchange on the summit of Mt Everest. Respir Physiol 1980; 42: 1-16.

15. West JB, Lahiri S, Maret KH, Peters RM Jr, Pizzo CJ. Barometric pressures at extreme altitudes on Mt Everest: physiological significance. J Appl Physiol: Respirat Environ Exercise Physiol 1983; 54: 1188-1194.

16. West JB, Boyer SJ, Graber DJ, et al. Maximal exercise at extreme altitudes on Mount Everest. J Appl Physiol: Respirat Environ Exercise Physiol 1983; 55: 688-698.

17. Houston CS, Sutton JR, Cymerman A, Reeves JT. Operation Everest II: man at extreme altitude. $J$ Appl Physiol 1987; 63: 877-882. 